\title{
Three Minute that Could Save Your Life from Oral Cancer Reduce the Risk, Spot the Early Sign
}

\author{
Ashish Kumar* \\ Secretary-General in Dental \& Medical Foundation, India
}

Submission: October 28, 2017; Published: November 10, 2017

*Corresponding author: Ashish Kumar, Secretary-General in Dental \& Medical Foundation, India, Email: ashish.idst@gmail.com; www.drashishkumar.info

\section{Opinion}

Oral cancer is basically a type of cancer that occurs in your oral cavity. It is typically developed within early older age group and it occurs most often in men than women. Oral cancer includes the part of lip, oral cavity, nasopharynx and oropharynx and have a particularly high burden in South Central Asia due to risk factor exposure and for this comprehensive approach is needed like reduction of risk factor and early diagnosis. When oral cancer is found early and treated, before the time to spread to other area of body, survival rate almost double. If you give three minutes daily to just examine for what your mouth usually looks like and feels like, then you may be the first yourself who can notice any unusual signs that can be the early sign of oral cancer.

\section{These are the three-early sign which you need to notice yourself}

An ulceration that don't heal within three weeks, any red or white patch in the oral cavity, lump or swelling in the mouth or head and neck area if you have any doubt consult your dentist or doctor for final confirmation. Any of these could be early sign of oral cancer or may notice other symptoms that might signal a need for closer look. This can include throat tenderness and numbness or hoarseness of voice etc.

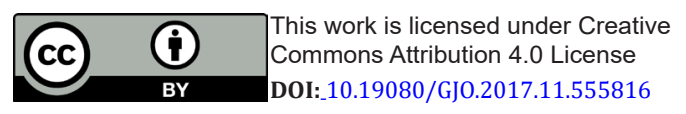

\section{Risk factor for oral cancer}

a) Use of tobacco

b) 2 alcohol

c) both combination of alcohol and tobacco

d) infection with human papilloma virus (HPV)

Everyone can reduce your risk of developing cancer by quitting the habits of tobacco, limiting your consumption of alcohol and most importantly avoid the combined consumption of both alcohol and tobacco.

\section{Spot the early sign}

Once you find any unusual finding inside or around your oral cavity consult your dentist or doctor to find out a serious killer in the name of oral cancer, which always try to hide right under your nose. Evaluating the any of these unusual finding is important but early detection of these increase the chance of good outcome.

\section{Acknowledgement}

Thanks to my mom-dad and my sister Dr. Anamika and my best friend Dr. Sonu kumar and all the member of DMF for your endless support and always motivating me for writing this.

Your next submission with Juniper Publishers will reach you the below assets

- Quality Editorial service

- Swift Peer Review

- Reprints availability

- E-prints Service

- Manuscript Podcast for convenient understanding

- Global attainment for your research

- Manuscript accessibility in different formats ( Pdf, E-pub, Full Text, Audio)

- Unceasing customer service

Track the below URL for one-step submission https://juniperpublishers.com/online-submission.php 